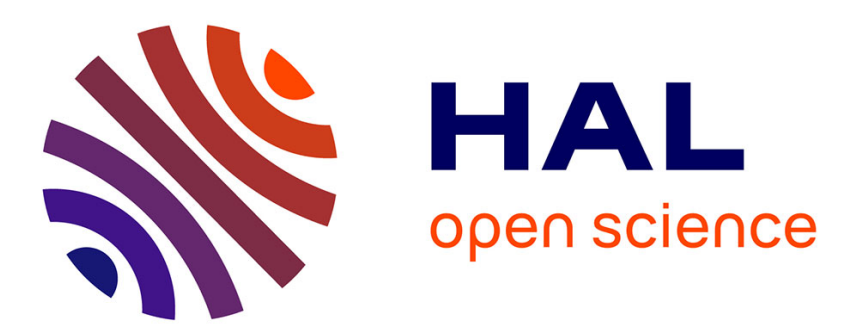

\title{
Effects of Price and Transportation Costs in Soybean Trade
}

João Reis, Pedro Amorim, José Cabral

\section{To cite this version:}

João Reis, Pedro Amorim, José Cabral. Effects of Price and Transportation Costs in Soybean Trade. IFIP International Conference on Advances in Production Management Systems (APMS), Sep 2016, Iguassu Falls, Brazil. pp.563-570, 10.1007/978-3-319-51133-7_67 . hal-01615775

\section{HAL Id: hal-01615775 \\ https://hal.inria.fr/hal-01615775}

Submitted on 12 Oct 2017

HAL is a multi-disciplinary open access archive for the deposit and dissemination of scientific research documents, whether they are published or not. The documents may come from teaching and research institutions in France or abroad, or from public or private research centers.
L'archive ouverte pluridisciplinaire $\mathbf{H A L}$, est destinée au dépôt et à la diffusion de documents scientifiques de niveau recherche, publiés ou non, émanant des établissements d'enseignement et de recherche français ou étrangers, des laboratoires publics ou privés.

\section{(c)(1)}

Distributed under a Creative Commons Attribution| 4.0 International License 


\title{
Effects of Price and Transportation Costs in Soybean Trade
}

\author{
João Gilberto Mendes dos Reis ${ }^{1}$, Pedro Amorim² ${ }^{2}$ and José António S. Cabral ${ }^{2}$ \\ 1 Paulista University, Postgraduate Studies Program in Production Engineering, \\ Dr. Bacelar St. 1212, São Paulo, Brazil \\ 2 University of Porto, Department of Engineering and Industrial Management \\ R. Dr. Roberto Frias s/n, Porto, Portugal \\ betomendesreis@msn.com; pamorim@fe.up.pt; jacabral@fe.up.pt
}

\begin{abstract}
The United States, Brazil, and Argentina are responsible for $83 \%$ of world's soybean production. Together, they respond to more than $80 \%$ of soybean grains and soybean meal exported and for more than $60 \%$ of soybean oil exportation. This paper studies the soybean trade of these three major exporters with the top ten commercial partners of each one in order to examine the main factors that influence this relationship. We follow a network analysis approach to evaluate the level of interdependence between exporters and importers. Our research studies the three main soybean products: grain, meal, and oil. The findings seem to indicate that countries prefer importing soybean grains to process inside their borders due to commodity prices and logistics costs.
\end{abstract}

Keywords: Soybean production - Competitiveness - Logistics impacts - Network relationship

\section{Introduction}

The major players of soybean production in the world are the United States, Brazil and Argentina. During 2014/15 crop year, they were responsible for $83 \%$ of world's production and for $88.9 \%$ soybean grain exports [1]. Soybean is traded as whole soybean and through its two derivative products, soybean oil and soybean meal, result from pressing and separating soybeans, a process known as crushing [2]. Around $85 \%$ of soybean production is crushed, where soybean meal is processed into animal feed, soy flour and proteins, and soybean oil is refined as edible oil, fat acids, and biodiesel [3]. This market is of large significance as the soybean grain exported by the United States represented in 2014 around US\$ 23.8 billion, while in Brazil, in the same year, the value was US $\$ 23.3$ billion $[4,5]$. Despite these numbers, there are still many issues to be faced by the soybean supply chain to ensure animal and human supply around the world.

These issues are related to the agricultural inputs, production, logistics, environment and relationship among players. Cavalett and Ortega, for instance, argue that soybean production uses high amount of resources and for this reason the managers should adopt sustainable production for the long term environmental sustainability of this chain [6]. Denicoff et al. point out that transportation 
is an essential part of the soybean supply chain and the soybean growers depend on an efficient transportation system to move their crops and bring inputs such as fertilizer and seeds [7].

Several studies have realized the complexity of soybean supply chains to indicate ways of to improve seed characteristics, production, and marketing, and logistics costs $[8,9,10,11,12]$. However, these studies fail to understand the complexity of the partners relations in this network and its influence in decision making.

The aims of this paper are to analyze the soybean trade flows of the three major exporters with the top ten commercial partners of each one and to examine the main factors that influence this relationship. To that end, we studied the volume of transactions of soybean grain, soybean meal and soybean oil among them using network analysis, with the assistance of UCINET (C)software.

The paper is organized as follows. After this introduction, the second section presents the methodology. In the third section, we address the results and discussion, and in the final section, the conclusion and outlook of this study are presented.

\section{Methodology}

To examine the trade flows of the three major exports we use the following methodology, which is divided into five steps:

1. First: We mapped the soybean supply chain to understand the process, products and foreign markets using knowledge available in the literature.

2. Second: We identified the main products commercialized by soybean trade companies and processing industries in the international market. These products are grains, soybean meal, and soybean oil.

3. Third: We use the report "Oilseeds: World Market and Trade" of the United States Agriculture Department [1] to identify the major countries exporters of grains, soybean meal and oil and we selected the three major as individual countries. The reference was the 2014/15 crop year.

4. Four: We collected data about the exportations for these countries using as reference 2014, last year with real data of exportations available. The data were collected by the Foreign Agriculture Service of United States Department of Agriculture [4], the System of Analysis of the Foreign Trade Information of Ministry of Development, Industry and Foreign Trade of Brazil (MDIC) [13], and Statistical Annuary 2014 of the Rosario Board of Trade in Argentina [14]. We focus on our study on the ten major destinations of exports from Argentina, Brazil and United States.

5. Fifth: We organized the data of soybean trade between countries in groups of trade: Soybean total, Soybean grain, Soybean meal and Soybean oil. To perform the analysis, we use the software UCINET 6.0. According to Kim et al [15] "UCINET is a comprehensive software for analysis of social network data, which is the most widely accept as social network analysis (SNA) 
tool for conducting a structural analysis of inter-organizational networks". In this case, we adopt the countries as organizations, and quantity of exportation as a relation between exporters and importers. Furthermore, the UCINET program was chosen because it contains several networks analysis methods, such as centrality measures, subgroup identification, elementary graph analysis [15].

\section{Results and Discussion}

The major products of the soybean supply chain are grains, soybean meal, and oil. It is important to reiterate that, the United States, Brazil, and Argentina divide the first three places as major exporters for these kinds of products. Considering data provided by the United States Department of Agriculture [1] to the $2014 / 15$ crop year, they have responded to $88.3 \%$ of soybean grains exportation, $68 \%$ of soybean meal exportation, and $85.9 \%$ of soybean oil exportation. Brazil and the United States compete for the first place in soybean grain exports, in this case, Brazil exported 50,612 million metric tons (MT) face of the United States who exported 50,169 million metric tons, while Argentina is the major export of soybean meal and oil. According to Schnepf et al. [16] this situation occurs due to the decision of the Argentine government, in the 1990s, of aggregating value to the soybean supply chain exportations, selling processed soybean, once it could not compete with Brazil and the United States in the soybean grain market. Note that the major top importers from Argentina, except China, all those are peripheral markets neither served by Brazil and nor the United States.

\subsection{Soybean Trade}

First of all, our work analyzed the soybean supply chain market as a whole. To that end, we sum the exportations of soybean grains, soybean meal and soybean oil of the top ten major destinations from the United States, Brazil, and Argentina. We plotted a network using Netdraw module of UCINET software and the results can be seen in Figure 1.

The blue nodes represent the three major exporter countries, green nodes American countries, red nodes European countries, gray nodes Asian countries, yellow nodes African and Middle East countries. The major importer of these three countries is China that imports $53 \%$ of these total soybean products sent from the United States, Brazil, and Argentina. The network highlights the intensity of this relation through the line strength. China is the main actor in the network creating the hypothesis that it possesses a high centrality in this network. This hypothesis will be verified in further study.

We could identify that Argentina responds for secondary markets, such as Colombia, Peru, Poland, and Venezuela, except China. While Brazil is responsible for several important markets such as Germany, Japan, Netherlands, Spain, Taiwan, and the the United States competes with Brazil in these markets and 


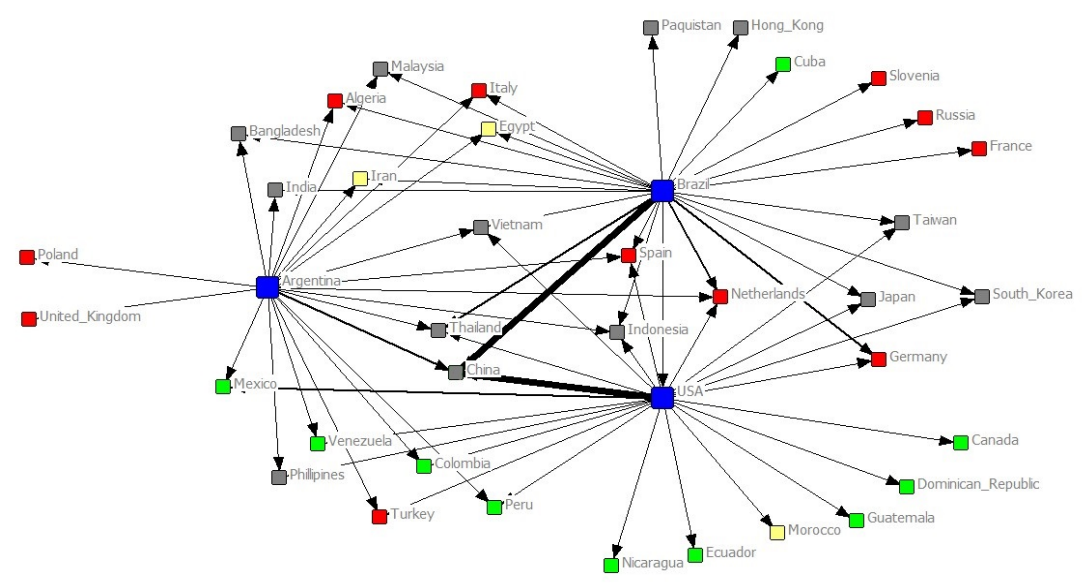

Fig. 1. Soybean supply chain export market to the three major players

attend secondary markets in America, such as Canada, Guatemala, Mexico, and Nicaragua.

Our study allows concluding that after China, the secondary important relations of Argentina, Brazil, and the United States are: Germany, Netherlands and Thailand. Therefore, further analysis will need to understand how the network reacts considering these markets together with China.

\subsection{Soybean Trade by Product}

In order to further understand the market of the soybean supply chain, we divide our analysis by product as it can be seen on the following networks (Figure 2, $3,4)$.

When we analyze Figure 2 is possible to conclude that China alone is the major importer of soybean grain. When we compare in numbers the three major export players sent to China in 2014 around $73.6 \%$ of its grains exported to the top ten major importers. About $75 \%$ of Chinese soybean demand is supplied by these countries [2]. This situation probably will not change, once China's arable lands and water supply in the main soybean production zone are rapidly diminishing [2]. China's increasing dependence on imported soybean is not only a result of its reduced capacity to produce soybeans, but also its increasing demand. The country is the most populous and the rising population purchasing power include more soy products in their diet, such as edible oil and demand for meat that is fed with soybean meal [2]. The graphic analyzed allow also conclude that Brazil exports to European countries and the Asian market, the United States competes with Brazil and export grains to South Korea, while Argentina, beyond the China, sell to peripheral markets, such as Bangladesh, Colombia, and Venezuela. 


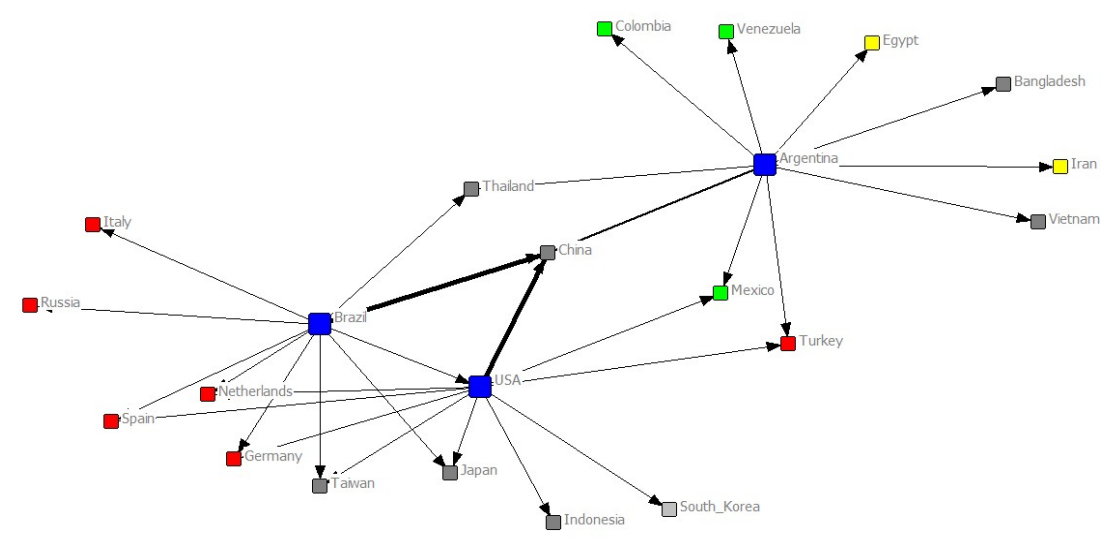

Fig. 2. Soybean grains export market to the three major players

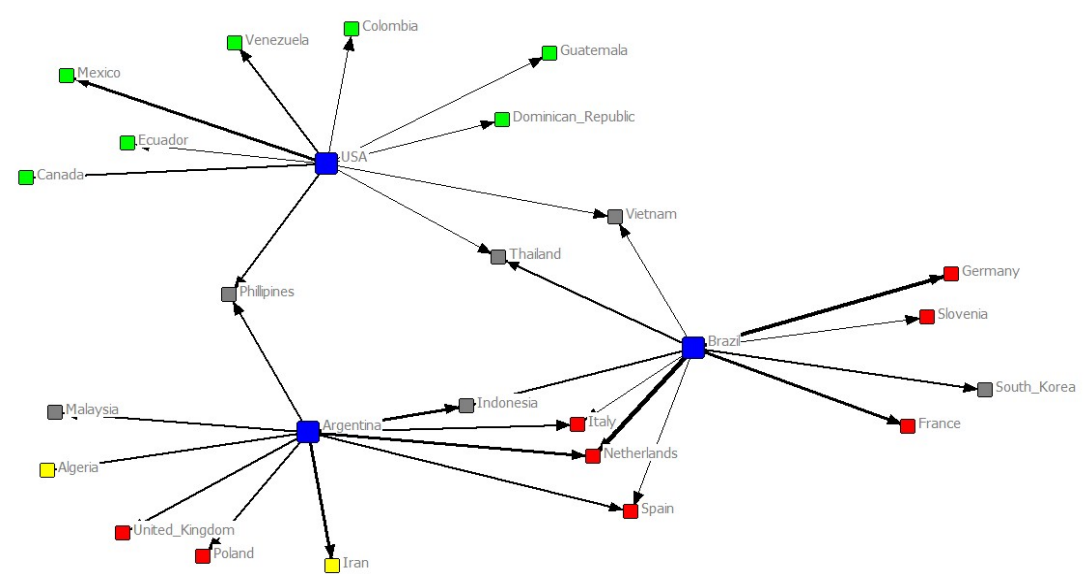

Fig. 3. Soybean meal export market of the three major players

When we analyze Figure 3 is possible to observe that in soybean meal China does not appear as a top importer. The country prefers buying grains and aggregate value in Chinese soil because it has a developed industry in this area. The Chinese issue is the demand that is huge due to its population. We can observe that Thailand and Vietnam are a common market between Brazil and the United States, while Italy, the Netherlands, and Spain are common between Brazil and Argentina. The United States, in general, attends the near markets in Latin America, and Canada. Argentina appears with more strength in this case selling its soybean meal to Malaysia, Poland, the United Kingdom, for example. Brazil exports the soybean meal most to Europe. 


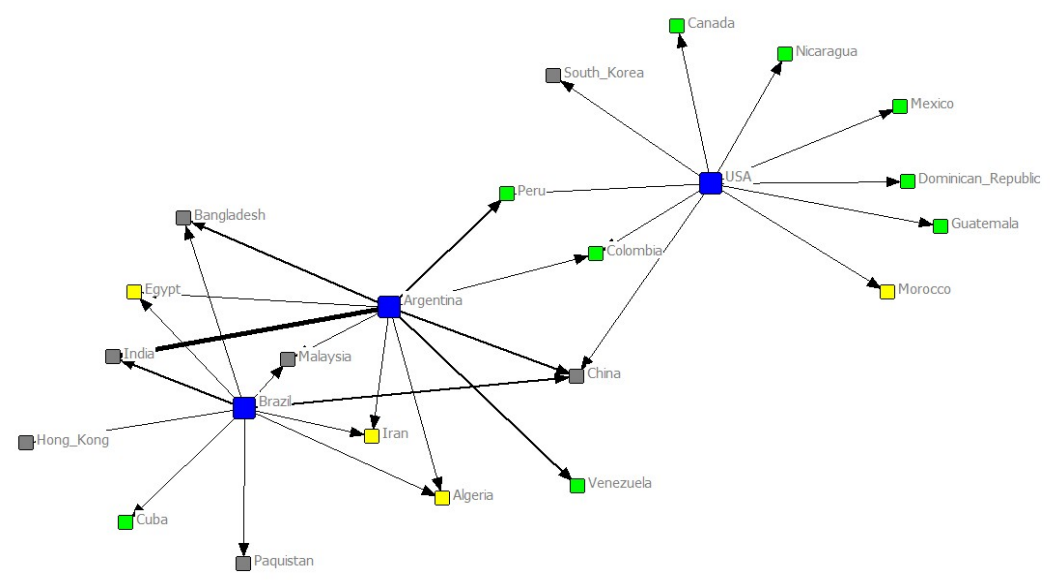

Fig. 4. Soybean oil export market of the three major players

Finally, when we analyze Figure 4 is clear that Argentina is the major exporter. In numbers, the country is responsible for $63.6 \%$ of what the three major exporters send for ten top major importers. Argentina and Brazil compete directly for the same market, while the United States commercializes in secondary markets that include Canada, Dominican Republic, Mexico, and Nicaragua. India is the major importer of soybean oil, in 2014 the country was the major commercial partner of Argentina and Brazil with $43.4 \%$ of exportations.

\subsection{Factors that Influence Soybean Trade}

Countries are searching for competitive advantages and if they have an efficient industry to aggregate value to the agricultural products, they will go buy soybean grains rather than processed products. When we analyze prices of soybean products there is a striking difference. In 2014, for example, the average price of soybean grain FOB according to Chicago Trade Board was US $\$ 492.50$ to soybean grain ton, US\$ 482.24 to soybean meal ton and US\$ 833.6 to soybean oil ton [14]. Furthermore, the transportation costs influence directly the volume of soybean grains moved around the world. The transportation systems are controlled by trading companies and the high volume ensures transportation cost reduction. Ocean rates from Brazil to Shangai in China reduced from US\$ 42.12 in 2013 to US\$ 37.57 in 2014 [10]. Table 1 compares the transportation costs among the United States, Brazil and Argentina to Shangai in August 2014 [17].

As can be seen in Table 1, Brazil has a slight advantage of the freight rate when to compare Argentina and the United States, however, its internal transportation cost is higher. If we compare the soybean oil with soybean grain and soybean meal, we realize that seen more interesting to buy grain and not soybean oil for the importer countries. Note that soybean meal is a residue of soybean oil extraction, therefore its price is almost the same of grain. Table 2, summarize the 
Table 1. Transport costs

\begin{tabular}{lrrr}
\hline & Argentina & Brazil United States \\
\hline Cargo mean quantity (ton) & 60,000 & 66,000 & 56,000 \\
Nautical miles & 11,186 & 11,031 & 9,977 \\
Total voyage (days) & 66.5 & 65 & 60 \\
Freight rate (US\$) & $55.06^{2}$ & 45.68 & 56.67 \\
\hline
\end{tabular}

comparison of transportation and commodity cost for the United States (more expensive) to show the difference between soybean grain and oil $[14,17]$.

Table 2. Comparison between soybean grain and soybean oil

\begin{tabular}{lrr}
\hline & \multicolumn{1}{c}{ Grain } & \multicolumn{2}{c}{ Oil Difference } \\
\hline Price (US\$) & 492.54833 .66 & $69 \%$ \\
Freight rate (US\$) & 56.67111 .58 & $96 \%$ \\
Total (US\$) & 549.21945 .24 & $72 \%$ \\
\hline
\end{tabular}

\section{Conclusions and Outlook}

In this paper, we used UCINET software to produce the supply network for soybean trade. Our analysis considers the volume of exportation between three major exporters and its top ten major importers. In this research, we focus on analyzing the relationships in the networks considering the size of the player and the strength of relationships through the size of the link between countries. The tools are based on social network analysis and can be pretty useful in the study of enterprises or organization's relationship. As the work is exploratory, we only focus on the graphic network relationship, leaving SNA social network analysis measures for further studies.

Through this analysis, we conclude that commodities and transportation prices are the main factors in soybean trade. The countries prefer to pay less for raw material and afterward process it in own country. The major reasons for that are the low transportation cost between origin port and destinations, and the difference between the price of soybean grain and of soybean oil. However, this work represents only a preliminary attempt to establish such a link.

Soybean is the main product to animal nutrition and has a huge market for the grains and sub products like edible oil for human consumption. Therefore, study the characteristics of this market, process and logistics are essential to creating a supply chain that is more efficient, and without losses and wastes. Furthermore, the next steps of this research will be to conduct a study evaluating the impact of logistics on the competitiveness of the soybean supply chain analyzing the countries involved. 


\section{References}

1. U.S. Department of Agriculture, Foreign Agriculture Service: Oilseed: World Market and Trade. Tech. rep., FAS/USDA (2015)

2. Brown-Lima, C., Cooney, M., Cleary, D.: An Overview of the Brazil-China Soybean Trade and its Strategic Implications for Conservation. Tech. rep., The Nature Conserancy (2012)

3. Murphy, S., Burch, D., Clapp, J.: Cereal secrets: The World's Largest Grain Traders and Global Agriculture. Tech. rep., OXFAM (2012)

4. U.S. Department of Agriculture, Foreign Agriculture Service: http://apps.fas . usda.gov/gats/default.aspx

5. Brazilian Agricultural Research Corporation: https://www.embrapa.br/soja/ cultivos/soja1/dados-economicos

6. Cavalett, O., Ortega, E.: Emergy and Fair Trade Assessment of Soybean Production and Processing in Brazil. Management of Environmental Quality: An Int. J. 18, 657-668 (2007)

7. Denicoff, M., Prater, M.E., Bahizi, P.: Soybean transportation profile. Tech. rep., U.S. Department of Agriculture, Foreign Agriculture Service (2014)

8. Hossain, Z., Mustafa, G., Sakata, K., Komatsu, S.: Insights into the Proteomic Response of Soybean Towards $\mathrm{Al} 2 \mathrm{O} 3, \mathrm{ZnO}$, and Ag Nanoparticles Stress. J. Hazard. Mater. 304, 291-305 (2016)

9. Hasan, N., Suryani, E., Hendrawan, R.: Analysis of Soybean Production and Demand to Develop Strategic Policy of Food Self Sufficiency: A System Dynamics Framework. In: The Third Information Systems International Conference. vol. 72, pp. 605-612 (2015)

10. Salin, D.: Soybean Transportation Guide: Brazil 2014. Tech. rep., U.S. Department of Agriculture, Foreign Agriculture Service (2015)

11. Zhang, L.w., Feike, T., Holst, J., Hoffmann, C., Doluschitz, R.: Comparison of Energy Consumption and Economic Performance of Organic and Conventional Soybean Production: A Case Study from Jilin Province, China. J. Integr. Agric. 14, 1561-1572 (2015)

12. Wei Chen, Mary A. Marchant, Andrew Muhammad: China's Soybean Product Imports: An Analysis of Price Effects Using a Production System Approach. China Agricultural Econ. Rev. 4, 499-513 (2012)

13. Brazilian Ministry of Development and Foreign Trade: http://aliceweb. desenvolvimento.gov.br/

14. Bolsa de Comercio de Rosario: Statistical Annuary. Tech. rep., Bolsa de Comercio de Rosario (2014)

15. Kim, Y., Choi, T.Y., Yan, T., Dooley, K.: Structural investigation of supply networks: A social network analysis approach. Journal of Operations Management 29(3), 194-211 (2011)

16. Schnepf, R.D., Dohlman, E., Bolling, C.: Agriculture in Brazil and Argentina: Developments and Prospects for Major Field Crops. Tech. rep., U.S. Department of Agriculture, Economic Research Service (2001)

17. O'Neil, J.: U.S. - South America Ocean Grain Freight Spreads. Tech. rep., IGP Technical Report (2015) 